\title{
Physical and Mechanical Properties of Cemented Ash-Based Lightweight Building Materials with and without Pumice
}

\author{
Neslihan Doğan-Sağlamtimur $\mathbb{D}^{1}{ }^{1}$ Adnan Güven, ${ }^{2}$ and Ahmet Bilgil ${ }^{3}$ \\ ${ }^{1}$ Department of Environmental Engineering, Niğde Ömer Halisdemir University, 51240 Niğde, Turkey \\ ${ }^{2}$ ÇIMSA Cement Industry and Trade Inc. Co. Niğde Plant, Hacı Sabancı Avenue, Niğde, Turkey \\ ${ }^{3}$ Department of Civil Engineering, Niğde Ömer Halisdemir University, 51240 Niğde, Turkey \\ Correspondence should be addressed to Neslihan Doğan-Sağlamtimur; neslihandogansaglamtimur@gmail.com
}

Received 8 November 2017; Revised 15 February 2018; Accepted 26 February 2018; Published 2 April 2018

Academic Editor: Cristina Leonelli

Copyright (C) 2018 Neslihan Doğan-Sağlamtimur et al. This is an open access article distributed under the Creative Commons Attribution License, which permits unrestricted use, distribution, and reproduction in any medium, provided the original work is properly cited.

\begin{abstract}
Pumice, cements (CEM I- and CEM II-type), waste fly and bottom ashes (IFA, GBA, and BBA) supplied from international companies were used to produce lightweight building materials, and physical-mechanical properties of these materials were determined. Axial compressive strength (ACS) values were found above the standards of 4 and $8 \mathrm{MPa}$ (Bims Concrete (BC) 40 and $80 \mathrm{kgf} / \mathrm{cm}^{2}$ class) for cemented (CEM I) pumice-based samples. On the contrary, the ACS values of the pumice-based cemented (CEM II) samples could not be reached to these standards. Best ACS results (compatible with BC80) from these cemented lightweight material samples produced with the ashes were found in $50 \%$ mixing ratio as 10.6, 13.2, and $20.5 \mathrm{MPa}$ for BBA + CEM I, GBA + CEM II, and IFA + CEM I, respectively, and produced with pumice were found as $8.4 \mathrm{MPa}$ (same value) for GBA + pumice + CEM II (in 25\% mixing ratio), BBA + pumice + CEM I (in 100\% mixing ratio), and pumice + IFA + CEM I (in 100\% mixing ratio), respectively. According to the results, cemented ash-based lightweight building material produced with and without pumice could widely be used for constructive purposes. As a result of this study, an important input to the ecosystem has been provided using waste ashes, whose storage constitutes a problem.
\end{abstract}

\section{Introduction}

In the industry, there is the tripod of raw material-process product, and waste formation is an inevitable problem in most industrial establishments [1]. Today, at the peak of environmental problems and raw material prices, the utilization of industrial wastes as an additive material in lightweight construction technology is one of the important issues that should be considered $[1,2]$.

The waste ash, which poses a serious problem for their storage and disposal, is being used for different purposes throughout the world and Turkey. Utilization of millions of tonnes of new waste that emerges every year and contributes unignorably to the already existing environmental catastrophe can only be substantial in sectors that consume large amounts, such as the construction sector. For this reason, the utilization of waste as building material, thus preventing the increase of deposited waste amounts, is one of the main targets of many scientific research [3, 4]. In this study, a selection was made within the coal ash utilization alternatives, and the conversion to lightweight building material came to the forefront. In this selection, the construction sector was considered because it meets the most basic need of people that is housing, it has a leveraging role for the world and the Turkish economy with the added value and employment opportunities it has created, and it has an annual growth rate of $7.1 \%$ and a share of $6 \%$ in the gross national product (GNP); and lightweight building materials were considered because they have a high market value, they have superiority as a building material, they demonstrate high strength, and they are one of the most used materials per person after water [5].

Bottom ash (BA), which is a kind of industrial solid waste, is released after combustion of coal $[1,4,6]$. 
BA having a size of $0.1-10 \mathrm{~mm}$ and a distinctive dark grey colour is usually not spherical [7]. It is mostly composed of silicate, carbonate, aluminate, iron, and various metals and metalloids. The exact composition of BA may depend on the source of raw coal product, its size, the type of coal burner, and the operating conditions of the burner [8]. Large-sized BAs $(>6 \mathrm{~mm})$ can be used as coarse aggregates, while small ones are suitable for use as fine aggregates [7]. Bai et al. [9] investigated the effect of BA on concrete properties in which BA was replaced with natural sand at various rates from $30 \%$ to $100 \%$. They investigated the strength and shrinkage properties of concrete where BA was used as a fine aggregate and reached the conclusion that $\mathrm{BA}$ can be used, replacing fine aggregate at a ratio of $30 \%$. Yüksel et al. [10] reported that the use of BA as a fine aggregate improves the porosity of concrete and that the use of BA makes it possible to produce durable concrete. Nataraj et al. [11] suggested that the use of BA in concrete is an alternative to the use of aggregate in concrete. Jayaranjan et al. [8] pointed out based on the literature that BAs with relatively high specific gravity (1.9-3.0) should be used in engineering applications.

As a type of industrial solid waste, the fine-grained ash is called fly ash (FA). Its atmospheric release from the dustholding units of pulverized coal-fired burners, especially in thermal power plants, is blocked by electrofilters [12]. The basis of FA is mainly composed of alumina silicates; alkalis, metals, and heavy metals, which can be found in small quantities with alumina silicates; and rarely soil. FA, known as the most modern material obtained as artificial pozzolan based on its chemical composition, can be used in many areas such as ceramics, plastic, wastewater treatment, cement, concrete, brick, lightweight aggregate, aerated concrete, and roads, especially in the construction sector [13]. Alkaya [14] examined the use of FAs in soil improvement. In their study, Sancak and Şamandar [12] investigated the amounts of use of blast furnace slag per FA, silica fume, and granule. They pointed out the possible contribution of waste materials to the self-compacting concrete production in terms of sustainability. Phonphuak et al. [15] demonstrated that they could achieve a lightweight building material by using FA and glass powder as the raw material with borax.

The benefits that can be achieved with the use of BAs and FAs are not limited to environmental protection and energy savings. Within the concept of industrial ecology, Basheer et al. [16] and Deja [17] had investigated the effects of this type of waste ash on concrete by using it as a mineral additive or aggregate in concrete production. Today, only $30 \%$ of the total ash produced in the world is reused, so the reuse of FAs and BAs is an important job [8].

Pumice, which is formed as a result of magma's solidification on the earth or at depths very close to the earth, is a magmatic (volcanic) rock. It has a unit weight (UW) less than $1 \mathrm{~g} / \mathrm{cm}^{3}$ and a porous, glassy, acidic, and basic characteristic. The pumice is in white, grey, and cream colours. This raw material does not sink when thrown into the water because it contains a large amount of gas space in the form of a foam or sponge. While it has an acid-medium composition, it contains crystal water. Because of these properties, it does not expand when heated [18]. Pumice concrete can exhibit more elastic behaviour against earthquake loads than normal concrete. Moreover, pumice concrete and building components are not affected by frost [19]. Acidic pumice, which is the most widely found on earth and the most widely used type, is white and dingy in colour, and basic pumice is blackish in colour. There are widespread uses in the construction industry due to the higher silica content in pumice with acidic character [20]. $80 \%$ of the pumice produced in Turkey is used as lightweight concrete aggregate in construction sector in the domestic market. In their study, Ünal et al. [21] investigated the effect of using pumice and Afyon Tinaztepe regional diatomite materials in the production of lightweight concrete block elements on properties of concrete. In their experimental study, they produced different series at different ratios by using pumice and diatomite of three different grain groups as lightweight aggregate, sand and crushed sand as normal aggregate. At the end of their study, they reached the conclusion that pumice and diatomite could be used instead of brick-like partition elements by utilizing the production of lightweight concrete block elements. They also concluded that besides the benefits to the economy, the issue of insulation in buildings could be solved with the use of them. Turkey, which has an important place in terms of pumice reserves in the world (with almost $40 \%$ of the world pumice reserves), has a very high market opportunity with pumice varieties of about ten different colours and texture qualities.

Lightweight building materials give the building a special character. Turkey has a geological structure in which fault and fracture systems can lead large earthquakes. There have been earthquakes in Turkey that cause big loss of life and property in short time intervals like 3 to 5 years. In developed countries such as Japan and the USA, it is no coincidence that there is little or no loss of life and property in 7.4 magnitude earthquakes. The reason for this is advanced construction technologies and the use of lightweight materials such as pumice, perlite, and aerated concrete in buildings. Lightweight materials significantly reduce building loads. The severe tremors in the horizontal and vertical directions, which are formed by an earthquake, are absorbed by porous materials, and thus buildings are shaken but not collapsed [22]. Another important point is that energy savings of up to $50 \%$ in the heating and cooling costs of buildings using lightweight building materials are ensured. Even in cold countries such as Sweden and Norway, which import and use lightweight building materials such as pumice, perlite, and aerated concrete, the heating cost of a house is less than half the heating cost of the equivalent house in Turkey. Qiao et al. [23] produced a lightweight building material (less than $1.8 \mathrm{~g} / \mathrm{cm}^{3}$ in density) with a compressive strength of 28 days, which was higher than $10 \mathrm{MPa}$. They found that the samples containing BA of a waste incineration plant were suitable for use as a lightweight building material based on the density and compressive strength results. Wongkeo and Chaipanich [24] conducted compressive strength, microstructural, and thermal analyses on the lightweight building material made of BA and silica fume. The compressive strength of the BAadded lightweight building material was found to increase 
TABLE 1: Chemical analysis of waste ashes and pumice.

\begin{tabular}{lcccc}
\hline \multirow{2}{*}{ Element (\%) } & \multicolumn{4}{c}{ Raw material } \\
& Pumice & IFA & GBA & BBA \\
\hline $\mathrm{SiO}_{2}$ & 70.09 & 58.05 & 27.36 & 27.98 \\
$\mathrm{Al}_{2} \mathrm{O}_{3}$ & 11.92 & 21.23 & 12.68 & 10.30 \\
$\mathrm{Fe}_{2} \mathrm{O}_{3}$ & 2.74 & 6.73 & 8.23 & - \\
$\mathrm{CaO}$ & 3.84 & 4.76 & 39.31 & 7.97 \\
$\mathrm{MgO}$ & 0.88 & 1.71 & 0.74 & 1.64 \\
$\mathrm{SO}_{3}$ & 0.10 & 0.15 & 5.94 & 10.35 \\
$\mathrm{~K}_{2} \mathrm{O}$ & 2.71 & 1.80 & 0.43 & 0.82 \\
$\mathrm{Na}_{2} \mathrm{O}$ & 4.70 & - & 1.88 & 0.46 \\
$\mathrm{Cl}$ & 0.13 & - & - & - \\
$\mathrm{P}_{2} \mathrm{O}_{5}$ & - & 0.20 & - & 0.35 \\
$\mathrm{TiO}_{2}$ & - & 1.22 & - & 7.97 \\
\hline
\end{tabular}

when silica smoke was added into the mixture. When using $5 \%$ silica fume and $20 \%$ BA mixture, they determined that a higher compressive strength was reached than the Portland cement control group. Blomqvist et al. [25] addressed the use of reusable lightweight materials in temporary buildings.

In this study, it was aimed to solve the waste ash problem emerging from coal, which is used for producing energy in the industry and thermal power plants, as well as producing lightweight building materials by evaluating the utilization efficiency of BA, FA, pumice, and cement. The study is quite detailed and different with various combinations of waste ashes, pumice, and cement of different types from different industries. It has given a new dimension to the existing knowledge of lightweight building materials.

\section{Materials and Methods}

2.1. Material. Cement is a calcium-based material that is used as a binder in the construction sector. Two types of cement that are CEM I 42.5 R-type Portland cement (hereinafter referred to as CEM I) and CEM II/A-L 42.5-type (Super Bims, hereinafter referred to as CEM II) Portland calcareous cement were used in this study as binders. Physical and chemical properties of these cements were not determined. Instead of this, the production values of the producer company were taken into consideration. The initial setting time and the final setting time were determined as 210 and 265 minutes and 510 and 550 minutes for CEM I and CEM II cements, respectively. The UWs of these cements were found to be 1.40 and $1.35 \mathrm{~g} / \mathrm{cm}^{3}$, respectively.

BA and FA used in this study as raw material were obtained from international companies that are Göknur Foodstuff Co. Nigde Factory (GBA: 700-1500 tons/year), Bor Sugar Factory (BBA: 17,000-19,000 tons/year), and İSKEN Inc. Co. Sugözü Thermal Power Plant (IFA: 300,000 tons/year). After bringing to laboratory, the raw materials were oven dried and sieved with $1 \mathrm{~mm}$ square sieve. During the sieving, coarse materials (1\%, $3 \%$, and $25 \%$ from IFA, GBA, and BBA, resp.) were stayed on the sieve.

The acidic pumice used in the study is supplied from Nevşehir province. The pumice beds in Nevşehir and in its vicinity have a quality that is preferred by many sectors. Grain size of this pumice generally ranges from 1 to $70 \mathrm{~mm}$.
The reason for preferring acidic pumice is that its UW is about $0.6 \mathrm{~g} / \mathrm{cm}^{3}$ and it can react better with cement. Pumice was separated into two parts including coarse and fine particles that were stayed on $1 \mathrm{~mm}$ square sieve (particle size is between 1 and $8 \mathrm{~mm}$ ) and passed through this sieve (particle size is from 0 to $1 \mathrm{~mm}$ ), respectively. The UWs of coarse and fine pumices are 0.53 and $0.91 \mathrm{~g} / \mathrm{cm}^{3}$. On the other hand, the UWs of GBA, BBA, and IFA were determined as $0.55,0.78$, and $0.91 \mathrm{~g} / \mathrm{cm}^{3}$, respectively.

According to standard test methods, chemical analysis of raw materials used in this study was done by Laboratory of ÇIMSA Cement Inc. Co. Niğde Factory and is given in Table 1.

The granulometric distribution of the pumice sieved with $8 \mathrm{~mm}$ square sieve, IFA, GBA, and BBA sieved with $1 \mathrm{~mm}$ square-mesh sieve are given in Figure 1.

2.2. Method. The production parameters of pumice-based building blocks used in construction technology should be in compliance with Turkish Standard (TS) 3234 that are based on ASTM standard [26]. According to upper and lower limits of this standard, the granulometric distribution of the materials was adjusted to produce samples having maximum compactness and is given in Figure 2. When making of mix design of GBA + pumice-, BBA + pumice-, and IFA + pumice-based sample, the materials adjusted according to Figure 2 were used.

According to TS 3234, it is recommended to do mixing calculation on the weight basis. In this standard, when considering axial compressive strength (ACS) values, pumice-based samples are separated into three groups as Bims Concrete (BC) $40, \mathrm{BC} 80$, and $\mathrm{BC} 120$ (28-day ACS values of these concrete types are $4 \mathrm{MPa}\left(40 \mathrm{kgf} / \mathrm{cm}^{2}\right), 8 \mathrm{MPa}\left(80 \mathrm{kgf} / \mathrm{cm}^{2}\right)$, and $12 \mathrm{MPa}$ $\left(120 \mathrm{kgf} / \mathrm{cm}^{2}\right)$, resp.). Mixing design differs for each group. In this study, mixing calculations were used to obtain samples in accordance with $\mathrm{BC} 40$ and $\mathrm{BC} 80$. However, since the UW values of the materials in the study were quite different from each other, the volume basis was taken into consideration for determination of mixture parameters. In the study, two types of cement were used, and the samples were produced from five groups of different materials.

Coarse $(1-8 \mathrm{~mm})$ and fine $(0-1 \mathrm{~mm})$ materials were used in forming the groups and in the mixing calculations. Pumice was used as coarse material in the samples consisting of waste ash + pumice mixing. Waste ashes were used as fine material as a substituent of pumice.

In group 1, samples that include mixing of CEM I + pumice and CEM II + pumice were produced. This group is a comparison group to waste ash-added samples. BC40 and $\mathrm{BC} 80$ samples were produced according to mixing design that conforms to the TS 3234 standard [26].

In group 2, samples that include mixing of CEM I + pumice + IFA and CEM II + pumice + IFA were produced. IFA (as fine material) was substituted by pumice in 25,50 , 75 , and $100 \%$ ratios. In this group, all coarse materials $(1-8 \mathrm{~mm})$ are pumice. BC40 and BC80 samples were produced according to mixing design that conforms to the TS 3234 standard [26]. 


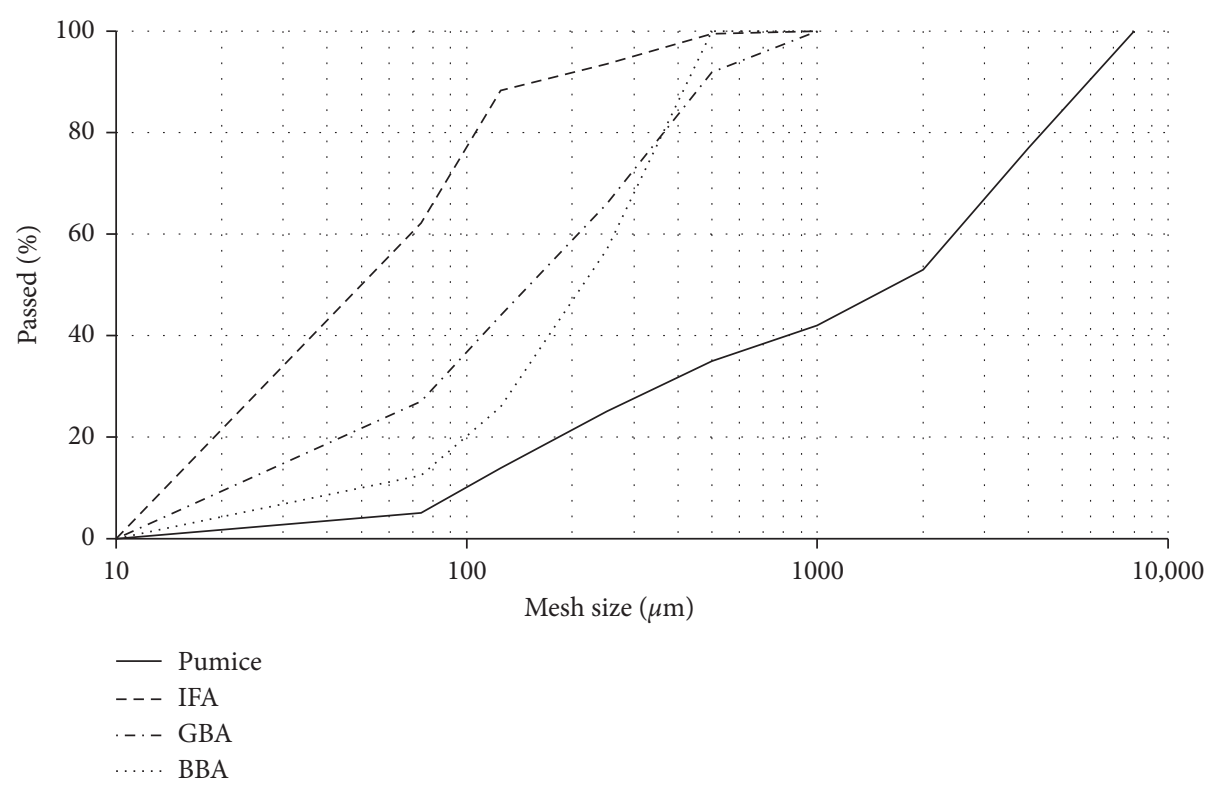

Figure 1: Granulometric distribution of pumice, IFA, GBA, and BBA.

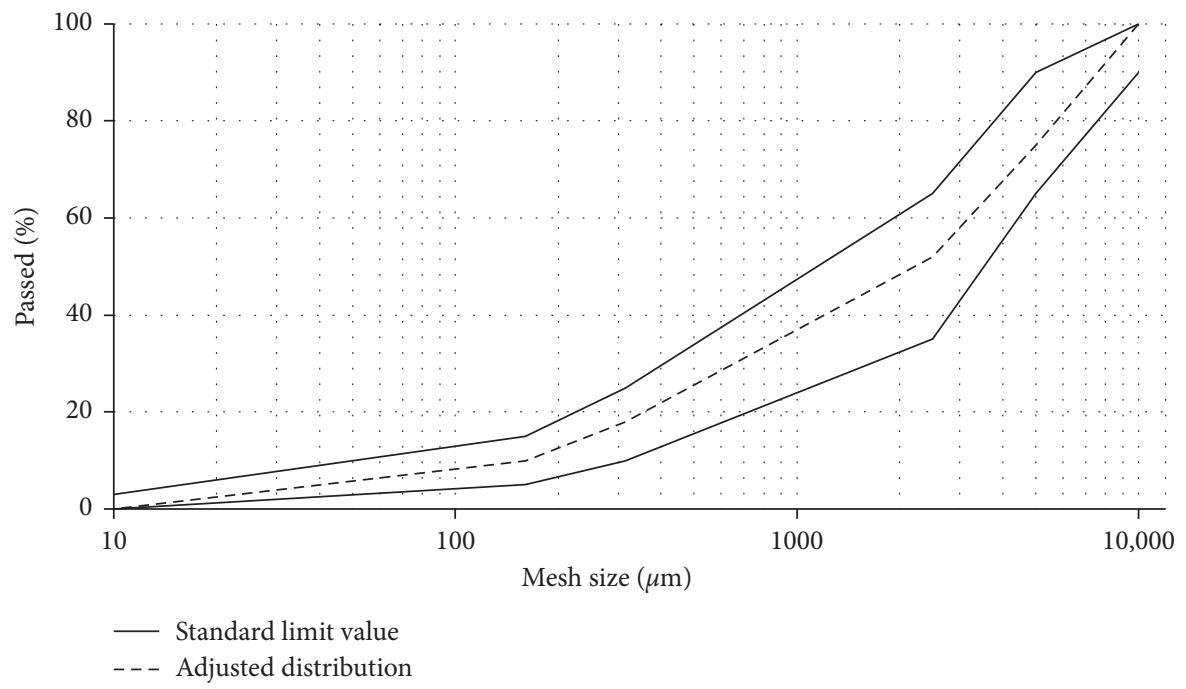

FIGURE 2: Grain-size curve of the pumice [26].

In group 3, BC40 and BC80 samples that conform to the TS 3234 standard [26] were produced from CEM I + pumice + GBA and CEM II + pumice + GBA mixing. GBA (as fine material) was substituted by pumice in $25,50,75$, and $100 \%$ ratios. In this group, all coarse materials are pumice.

In group 4, samples that include mixing of CEM I + pumice $+\mathrm{BBA}$ and CEM II + pumice + BBA were produced. BBA (as fine material) was replaced by pumice in 25 , 50,75 , and $100 \%$ ratios. In this group, all coarse materials are pumice. According to mixing design that conforms to the TS 3234 standard [26], BC40 and BC80 samples were produced.

In group 5, samples including only waste ashes were produced. The mixing calculation was not done in this group. In the sample production, waste ashes were bound with cement in 25,50,75, 100\% ratios (in volume basis).
Considering CEM I + IFA, CEM II + IFA, CEM I + GBA, CEM II + GBA, CEM I + BBA, and CEM II + BBA mixing, the experiments were designed.

\section{Experimental}

Samples produced were kept in molds $(40 \times 40 \times 160 \mathrm{~mm}$ in size) and placed with the help of vibration (Figure 3 ). 12 replicates were produced from each sample (Figure 4).

The consistency test-because water ratios may influence the sample properties-was carried out during the sample preparation, and the consistency intervals of all samples were kept constant. The percentage of combustible substances in FA and $\mathrm{BA}$ at $750^{\circ} \mathrm{C}$ was found to be 7,23 , and $24 \%$ for IFA, GBA, and BBA, respectively. The test samples, 


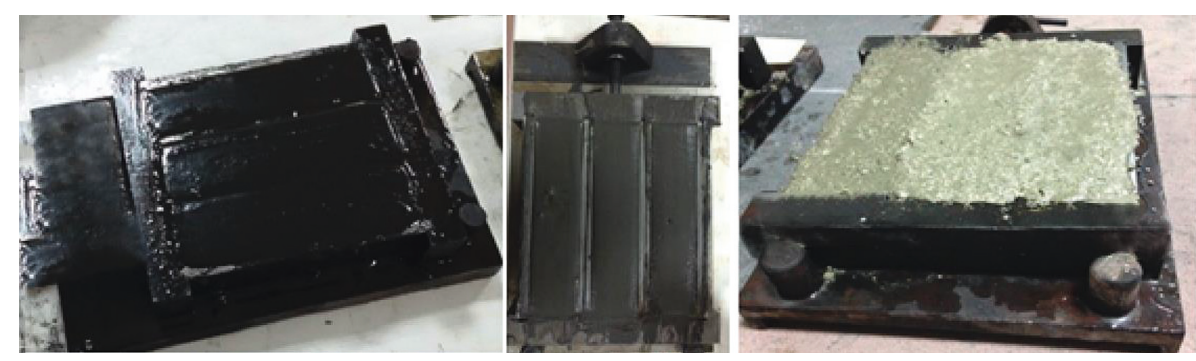

FIgURE 3: Some molded samples in this study.

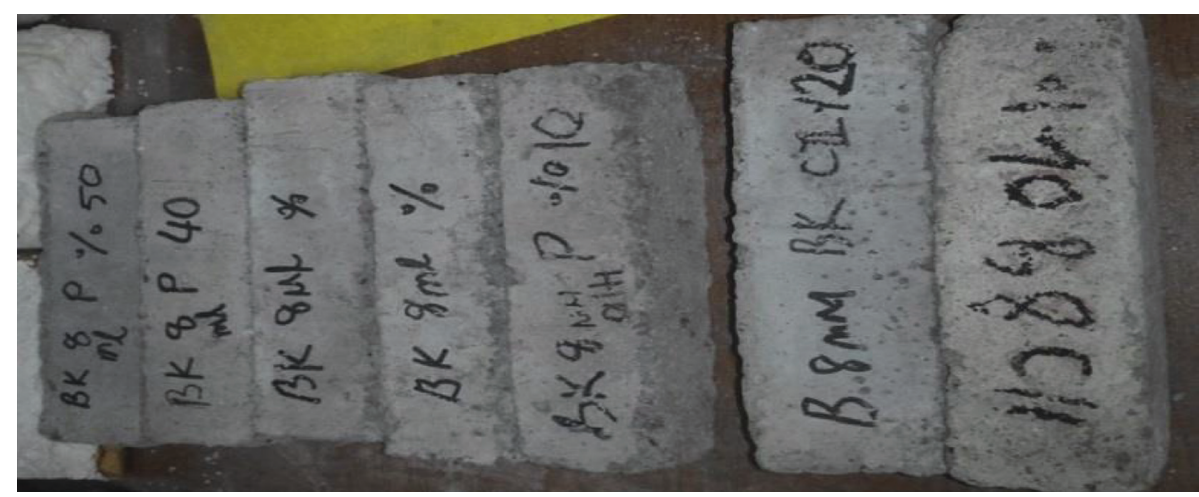

FIGURE 4: After water absorption percentage (WAP) experiment, photographs of some samples produced in this study. Note: the acronym of $\mathrm{BK}$ in this figure is in Turkish, indicating BBA.

which were separated into five different groups, were produced in the same environmental conditions as much as possible and were prepared for the experiment. Samples were kept in molds for $24 \mathrm{~h}$ after they were placed. These samples were taken out from the molds and water cure in $20 \pm 2^{\circ} \mathrm{C}$ temperature was applied for them. After curing/staying in water (Figure 4), 7- and 28-day ACS, UW, porosity, and WAP were determined. All the mentioned tests were made and assessed according to the relevant standard (TS 3234) [26].

\section{Results and Discussion}

Experiments conforming to the relevant standards were carried out on different proportions of pumice-, IFA-, BBA-, and GBA-based cemented (CEM I and CEM II) sample. These experiments included 7- and 28-day ACS, UW, WAP, porosity, and ACS after freeze-thaw. Findings of the results (as arithmetic mean values of each 3 samples) obtained from the experiments are given in Tables 2 and 3 altogether.

In this section, important parameters of cemented lowcost, durable lightweight building materials that are produced from pumice and waste ashes of two industrial plants and a thermal power plant that have different waste ash problems and different ash compositions are visualized in Figures $5-10$ to better interpret their performance assessment.

According to the increase of IFA fine material ratio, the ACS values are given in Table 2 and Figure 5 to samples produced with CEM I and CEM II and IFA. The ACS values were found in the range of 3.45-5.20 $\mathrm{MPa}$ (mean: $4.51 \mathrm{MPa}$ ) and 3.00-3.45 MPa (mean: 3.20 MPa) for BC40 and 6.708.40 MPa (mean: $7.75 \mathrm{MPa}$ ) and $4.20-5.20 \mathrm{MPa}$ (mean: $4.65 \mathrm{MPa}$ ) for BC80 in the samples produced with CEM Iand CEM II-type cement, respectively. For BC40 and BC80 Bims concrete classes, unlike the CEM I samples, the ACS values were decreased as the ash content increased in the CEM II samples.

As the ash content increased, the ACS values were increased and decreased in the CEM I + GBA and CEM II + GBA mixing samples, respectively, for BC40 and BC80. The ACS values were found in the range of $3.10-3.90 \mathrm{MPa}$ (mean: $3.44 \mathrm{MPa}$ ) and 2.75-3.30 MPa (mean: $3.00 \mathrm{MPa}$ ) for BC40 and 6.80-8.40 MPa (mean: $7.78 \mathrm{MPa}$ ) and 7.108.40 MPa (mean: $7.73 \mathrm{MPa}$ ) for BC80 in the samples produced with CEM I- and CEM II-type cement, respectively. However, the ACS values reached the standard [26] values (BC80) in the CEM I samples mixed with 75 and 100\% GBA ratios and in the CEM II samples mixed with 25 and 50\% GBA ratios (Table 2, Figure 5).

For BC40, the ACS values of the CEM I + BBA and CEM $\mathrm{II}+\mathrm{BBA}$ mixed samples were increased in the range of 4.30-5.20 MPa (average: 4.75 MPa) and decreased from 4.50 to $3.30 \mathrm{MPa}$ (average: $3.93 \mathrm{MPa}$ ), respectively, as a function of the percentage of BBA. On the other hand, for BC80, these values were increased from 6.70 to $8.40 \mathrm{MPa}$ (mean: $7.85 \mathrm{MPa}$ ) and decreased from 7.90 to $6.70 \mathrm{MPa}$ (mean: 7.25 MPa), in parallel with the increase of the BBA ratio. The CEM I and BBA samples having 50, 75, and 100\% mixing ratios exceeded the standard [26] (BC80) values (Table 2, Figure 5). 
TABLE 2: Experimental results of pumice-based lightweight materials.

\begin{tabular}{|c|c|c|c|c|c|c|c|}
\hline Sample* & $\begin{array}{c}\text { 7-day ACS } \\
(\mathrm{MPa})\end{array}$ & $\begin{array}{c}\text { 28-day ACS } \\
(\mathrm{MPa})\end{array}$ & $\begin{array}{l}\mathrm{UW} \\
\left(\mathrm{g} / \mathrm{cm}^{3}\right)\end{array}$ & $\begin{array}{l}\text { WAP } \\
(\%)\end{array}$ & Porosity & $\begin{array}{l}\text { ACS after freeze-thaw } \\
(\mathrm{MPa})\end{array}$ & $\begin{array}{l}\text { Loss of ACS after } \\
\text { freeze-thaw (\%) }\end{array}$ \\
\hline \multicolumn{8}{|c|}{ Pumice + IFA } \\
\hline BC40 CEM I + 0 & 2.25 & 5.24 & 0.77 & 45.60 & 38.40 & 3.80 & 27 \\
\hline $\begin{array}{l}\text { BC40 CEM I } \\
+25\end{array}$ & 1.35 & 3.45 & 0.90 & 53.50 & 38.10 & 2.80 & 18 \\
\hline $\begin{array}{l}\text { BC40 CEM I } \\
+50\end{array}$ & 2.00 & 4.60 & 0.92 & 52.70 & 37.60 & 3.70 & 20 \\
\hline $\begin{array}{l}\text { BC40 CEM I } \\
+75\end{array}$ & 1.90 & 4.80 & 0.95 & 52.80 & 36.80 & 3.80 & 21 \\
\hline $\begin{array}{l}\text { BC40 CEM I } \\
+100\end{array}$ & 2.45 & 5.20 & 0.97 & 52.60 & 36.70 & 4.00 & 24 \\
\hline $\begin{array}{l}\text { BC40 CEM II } \\
+0\end{array}$ & 2.10 & 4.17 & 0.75 & 42.60 & 39.80 & 3.20 & 23 \\
\hline $\begin{array}{l}\text { BC40 CEM II } \\
+25\end{array}$ & 0.80 & 3.45 & 0.91 & 41.60 & 38.70 & 2.80 & 19 \\
\hline $\begin{array}{l}\text { BC40 CEM II } \\
+50\end{array}$ & 0.95 & 3.30 & 0.94 & 40.90 & 38.40 & 2.60 & 21 \\
\hline $\begin{array}{l}\text { BC40 CEM II } \\
+75\end{array}$ & 1.30 & 3.05 & 1.07 & 40.30 & 39.20 & 2.30 & 25 \\
\hline $\begin{array}{l}\text { BC40 CEM II } \\
+100\end{array}$ & 1.60 & 3.00 & 1.16 & 40.00 & 39.10 & 2.20 & 26 \\
\hline BC80 CEM I + 0 & 3.82 & 9.25 & 0.87 & 41.70 & 40.90 & 7.80 & 16 \\
\hline $\begin{array}{l}\text { BC } 80 \text { CEM I } \\
+25\end{array}$ & 2.00 & 6.70 & 0.98 & 46.00 & 31.30 & 5.70 & 15 \\
\hline $\begin{array}{l}\text { BC80 CEM I } \\
+50\end{array}$ & 3.85 & 7.80 & 1.00 & 47.30 & 31.50 & 6.50 & 17 \\
\hline $\begin{array}{l}\text { BC } 80 \text { CEM I } \\
+75\end{array}$ & 3.35 & 8.10 & 1.02 & 51.70 & 33.50 & 6.50 & 20 \\
\hline $\begin{array}{l}\text { BC80 CEM I } \\
+100\end{array}$ & 4.25 & 8.40 & 1.09 & 53.80 & 34.80 & 6.70 & 20 \\
\hline $\begin{array}{l}\text { BC80 CEM II } \\
+0\end{array}$ & 4.15 & 8.36 & 0.85 & 39.80 & 44.50 & 7.20 & 14 \\
\hline $\begin{array}{l}\text { BC80 CEM II } \\
+25\end{array}$ & 2.50 & 5.20 & 0.94 & 53.30 & 38.30 & 4.30 & 17 \\
\hline $\begin{array}{l}\text { BC80 CEM II } \\
+50\end{array}$ & 2.40 & 4.70 & 0.96 & 53.40 & 38.80 & 3.80 & 19 \\
\hline $\begin{array}{l}\text { BC80 CEM II } \\
+75\end{array}$ & 2.25 & 4.50 & 1.04 & 42.80 & 38.00 & 3.60 & 21 \\
\hline $\begin{array}{l}\text { BC80 CEM II } \\
+100\end{array}$ & 1.70 & 4.20 & 1.18 & 41.10 & 37.20 & 3.20 & 23 \\
\hline \multicolumn{8}{|c|}{ Pumice + GBA } \\
\hline BC40 CEM I + 0 & 2.25 & 5.24 & 0.77 & 45.60 & 38.40 & 3.80 & 27 \\
\hline $\begin{array}{l}\text { BC40 CEM I } \\
+25\end{array}$ & 1.50 & 3.10 & 0.95 & 42.90 & 40.20 & 2.60 & 16 \\
\hline $\begin{array}{l}\text { BC40 CEM I } \\
+50\end{array}$ & 1.70 & 3.25 & 0.94 & 43.80 & 40.20 & 2.60 & 20 \\
\hline $\begin{array}{l}\text { BC40 CEM I } \\
+75\end{array}$ & 1.70 & 3.50 & 0.91 & 44.80 & 40.20 & 2.80 & 20 \\
\hline $\begin{array}{l}\text { BC40 CEM I } \\
+100\end{array}$ & 1.80 & 3.90 & 0.89 & 46.90 & 43.00 & 3.10 & 21 \\
\hline $\begin{array}{l}\text { BC40 CEM II } \\
+0\end{array}$ & 2.10 & 4.17 & 0.75 & 42.60 & 39.80 & 3.20 & 23 \\
\hline $\begin{array}{l}\text { BC40 CEM II } \\
+25\end{array}$ & 0.90 & 3.30 & 0.97 & 43.00 & 40.70 & 2.70 & 18 \\
\hline $\begin{array}{l}\text { BC40 CEM II } \\
+50\end{array}$ & 1.25 & 2.95 & 0.95 & 45.60 & 40.00 & 2.40 & 19 \\
\hline $\begin{array}{l}\text { BC40 CEM II } \\
+75\end{array}$ & 1.70 & 3.00 & 0.92 & 51.40 & 44.00 & 2.30 & 22 \\
\hline $\begin{array}{l}\text { BC40 CEM II } \\
+100\end{array}$ & 0.90 & 2.75 & 0.90 & 53.20 & 44.10 & 2.10 & 23 \\
\hline
\end{tabular}


TABle 2: Continued.

\begin{tabular}{|c|c|c|c|c|c|c|c|}
\hline Sample* & $\begin{array}{l}\text { 7-day ACS } \\
(\mathrm{MPa})\end{array}$ & $\begin{array}{l}\text { 28-day ACS } \\
(\mathrm{MPa})\end{array}$ & $\begin{array}{l}\text { UW } \\
\left(\mathrm{g} / \mathrm{cm}^{3}\right)\end{array}$ & $\begin{array}{l}\text { WAP } \\
(\%)\end{array}$ & Porosity & $\begin{array}{l}\text { ACS after freeze-thaw } \\
(\mathrm{MPa})\end{array}$ & $\begin{array}{l}\text { Loss of ACS after } \\
\text { freeze-thaw (\%) }\end{array}$ \\
\hline BC80 CEM I + 0 & 3.82 & 9.25 & 0.87 & 41.70 & 40.90 & 7.80 & 16 \\
\hline $\begin{array}{l}\text { BC80 CEM I } \\
+25\end{array}$ & 3.40 & 6.80 & 1.05 & 35.20 & 35.30 & 5.70 & 16 \\
\hline $\begin{array}{l}\text { BC80 CEM I } \\
+50\end{array}$ & 2.80 & 7.80 & 1.04 & 35.60 & 35.60 & 6.40 & 18 \\
\hline $\begin{array}{l}\text { BC80 CEM I } \\
+75\end{array}$ & 2.70 & 8.10 & 1.02 & 34.10 & 33.20 & 6.60 & 18 \\
\hline $\begin{array}{l}\text { BC80 CEM I } \\
+100\end{array}$ & 3.70 & 8.40 & 1.00 & 34.40 & 33.50 & 6.80 & 19 \\
\hline $\begin{array}{l}\text { BC } 80 \text { CEM II } \\
+0\end{array}$ & 4.15 & 8.36 & 0.85 & 39.80 & 44.50 & 7.20 & 14 \\
\hline $\begin{array}{l}\text { BC80 CEM II } \\
+25\end{array}$ & 2.90 & 8.40 & 1.09 & 38.70 & 38.70 & 6.70 & 20 \\
\hline $\begin{array}{l}\text { BC } 80 \text { CEM II } \\
+50\end{array}$ & 3.00 & 8.10 & 1.06 & 37.60 & 39.70 & 6.50 & 20 \\
\hline $\begin{array}{l}\text { BC80 CEM II } \\
+75\end{array}$ & 2.70 & 7.30 & 1.03 & 34.40 & 34.40 & 5.50 & 24 \\
\hline $\begin{array}{l}\text { BC80 CEM II } \\
+100\end{array}$ & 2.40 & 7.10 & 1.00 & 34.20 & 34.10 & 5.50 & 23 \\
\hline \multicolumn{8}{|c|}{ Pumice $+B B A$} \\
\hline BC40 CEM I + 0 & 2.25 & 5.24 & 0.77 & 45.60 & 38.40 & 3.80 & 27 \\
\hline $\begin{array}{l}\text { BC40 CEM I } \\
+25\end{array}$ & 1.45 & 4.30 & 1.05 & 44.40 & 40.40 & 3.40 & 20 \\
\hline $\begin{array}{l}\text { BC40 CEM I } \\
+50\end{array}$ & 0.90 & 4.70 & 0.97 & 44.20 & 40.30 & 3.80 & 20 \\
\hline $\begin{array}{l}\text { BC40 CEM I } \\
+75\end{array}$ & 1.00 & 4.80 & 0.93 & 43.30 & 41.60 & 3.70 & 22 \\
\hline $\begin{array}{l}\text { BC40 CEM I } \\
+100\end{array}$ & 0.75 & 5.20 & 0.92 & 44.60 & 42.90 & 3.90 & 25 \\
\hline $\begin{array}{l}\text { BC40 CEM II } \\
+0\end{array}$ & 2.10 & 4.17 & 0.75 & 42.60 & 39.80 & 3.20 & 23 \\
\hline $\begin{array}{l}\text { BC40 CEM II } \\
+25\end{array}$ & 1.25 & 4.50 & 1.08 & 45.20 & 41.10 & 3.60 & 21 \\
\hline $\begin{array}{l}\text { BC40 CEM II } \\
+50\end{array}$ & 0.80 & 4.30 & 1.06 & 44.30 & 40.80 & 3.40 & 22 \\
\hline $\begin{array}{l}\text { BC40 CEM II } \\
+75\end{array}$ & 1.30 & 3.60 & 1.01 & 38.50 & 38.60 & 2.80 & 23 \\
\hline $\begin{array}{l}\text { BC40 CEM II } \\
+100\end{array}$ & 1.40 & 3.30 & 1.00 & 38.30 & 37.80 & 2.40 & 26 \\
\hline BC80 CEM I + 0 & 3.82 & 9.25 & 0.87 & 41.70 & 40.90 & 7.80 & 16 \\
\hline $\begin{array}{l}\text { BC } 80 \text { CEM I } \\
+25\end{array}$ & 3.80 & 6.70 & 1.05 & 34.50 & 37.80 & 5.60 & 17 \\
\hline $\begin{array}{l}\text { BC80 CEM I } \\
+50\end{array}$ & 3.20 & 8.10 & 0.98 & 38.90 & 38.10 & 6.60 & 19 \\
\hline $\begin{array}{l}\text { BC80 CEM I } \\
+75\end{array}$ & 2.20 & 8.20 & 0.93 & 41.20 & 39.70 & 6.60 & 20 \\
\hline $\begin{array}{l}\text { BC80 CEM I } \\
+100\end{array}$ & 1.80 & 8.40 & 0.92 & 45.10 & 40.70 & 6.70 & 20 \\
\hline $\begin{array}{l}\text { BC80 CEM II } \\
+0\end{array}$ & 4.15 & 8.36 & 0.85 & 39.80 & 44.50 & 7.20 & 14 \\
\hline $\begin{array}{l}\text { BC80 CEM II } \\
+25\end{array}$ & 3.50 & 7.90 & 1.10 & 43.90 & 40.20 & 6.50 & 18 \\
\hline $\begin{array}{l}\text { BC80 CEM II } \\
+50\end{array}$ & 2.75 & 7.50 & 1.04 & 39.60 & 41.50 & 6.00 & 20 \\
\hline $\begin{array}{l}\text { BC80 CEM II } \\
+75\end{array}$ & 1.80 & 6.90 & 1.01 & 39.40 & 41.00 & 5.40 & 22 \\
\hline $\begin{array}{l}\text { BC80 CEM II } \\
+100\end{array}$ & 0.60 & 6.70 & 0.98 & 38.90 & 39.10 & 5.00 & 25 \\
\hline
\end{tabular}

${ }^{*}$ The values like +25 and +50 indicate fine material (waste ash) mixing ratios. 
TABLE 3: Experimental results of ash-based lightweight materials.

\begin{tabular}{|c|c|c|c|c|c|c|c|c|c|c|c|c|c|c|}
\hline \multirow[t]{3}{*}{$\begin{array}{l}\text { Cement amount } \\
\text { (in volume) (\%) }\end{array}$} & \multicolumn{2}{|c|}{$\begin{array}{l}\text { 7-day ACS } \\
(\mathrm{MPa})\end{array}$} & \multicolumn{2}{|c|}{$\begin{array}{l}\text { 28-day ACS } \\
(\mathrm{MPa})\end{array}$} & \multicolumn{2}{|c|}{$\mathrm{UW}\left(\mathrm{g} / \mathrm{cm}^{3}\right)$} & \multicolumn{2}{|c|}{ WAP (\%) } & \multicolumn{2}{|c|}{ Porosity } & \multicolumn{2}{|c|}{$\begin{array}{l}\text { ACS after } \\
\text { freeze-thaw } \\
(\mathrm{MPa})\end{array}$} & \multicolumn{2}{|c|}{$\begin{array}{c}\text { Loss of ACS } \\
\text { after } \\
\text { freeze-thaw } \\
(\%)\end{array}$} \\
\hline & CEM & CEM & CEM & CEM & CEM & CEM & CEM & CEM & CEM & CEM & CEM & CEM & CEM & CEM \\
\hline & I & II & I & II & I & II & I & II & I & II & I & II & I & II \\
\hline \multicolumn{15}{|c|}{$I F A$} \\
\hline 10 & 2.7 & 1.9 & 6.8 & 6.2 & 1.15 & 1.16 & 30.8 & 31.7 & 37.3 & 38.0 & 4.4 & 3.8 & 36.0 & 38.0 \\
\hline 20 & 3.3 & 2.5 & 9.0 & 10.1 & 1.22 & 1.25 & 30.8 & 30.8 & 35.8 & 37.3 & 5.9 & 6.7 & 34.0 & 34.0 \\
\hline 30 & 9.4 & 4.1 & 14.9 & 13.7 & 1.30 & 1.30 & 30.2 & 29.2 & 34.3 & 36.2 & 10.6 & 9.6 & 29.0 & 30.0 \\
\hline 40 & 10.2 & 5.3 & 18.9 & 13.8 & 1.36 & 1.39 & 29.4 & 28.7 & 33.1 & 35.2 & 14.4 & 10.2 & 24.0 & 26.0 \\
\hline 50 & 11.1 & 5.6 & 20.5 & 14.3 & 1.40 & 1.43 & 27.9 & 27.5 & 32.0 & 31.9 & 15.6 & 11.2 & 24.0 & 22.0 \\
\hline \multicolumn{15}{|c|}{$G B A$} \\
\hline 10 & 0.5 & 0.5 & 4.7 & 1.6 & 0.67 & 0.68 & 46.3 & 45.9 & 46.3 & 47.5 & 3.2 & 1.1 & 32.0 & 31.0 \\
\hline 20 & 1.6 & 0.8 & 7.0 & 3.9 & 0.77 & 0.78 & 45.8 & 45.2 & 45.1 & 46.1 & 5.0 & 2.8 & 28.0 & 28.0 \\
\hline 30 & 3.0 & 3.1 & 7.4 & 6.6 & 0.90 & 0.91 & 45.2 & 43.9 & 42.2 & 43.7 & 5.6 & 5.1 & 25.0 & 23.0 \\
\hline 40 & 5.5 & 5.4 & 9.4 & 7.8 & 1.02 & 1.01 & 44.1 & 42.6 & 40.8 & 41.7 & 7.4 & 6.1 & 21.0 & 22.0 \\
\hline 50 & 7.5 & 6.0 & 13.2 & 12.1 & 1.09 & 1.10 & 43.1 & 41.4 & 39.3 & 39.1 & 10.7 & 9.7 & 19.0 & 20.0 \\
\hline \multicolumn{15}{|c|}{$B B A(0-1 \mathrm{~mm})$} \\
\hline 10 & 0.5 & 0.6 & 2.4 & 1.6 & 0.93 & 0.94 & 47.2 & 47.5 & 48.3 & 46.2 & 1.9 & 1.2 & 21.0 & 24.0 \\
\hline 20 & 0.9 & 1.0 & 3.8 & 2.9 & 0.99 & 0.98 & 48.8 & 46.8 & 47.4 & 44.2 & 3.1 & 2.2 & 19.0 & 23.0 \\
\hline 30 & 2.1 & 2.3 & 5.1 & 4.5 & 1.06 & 1.17 & 45.0 & 44.8 & 44.3 & 42.4 & 4.1 & 3.6 & 19.0 & 20.0 \\
\hline 40 & 3.6 & 2.5 & 6.8 & 5.3 & 1.11 & 1.27 & 41.4 & 41.6 & 42.7 & 39.7 & 5.6 & 4.3 & 17.0 & 18.0 \\
\hline 50 & 5.3 & 2.9 & 9.3 & 6.7 & 1.18 & 1.31 & 40.5 & 39.1 & 41.1 & 38.1 & 7.9 & 5.6 & 15.0 & 16.0 \\
\hline \multicolumn{15}{|c|}{$B B A(0-8 \mathrm{~mm})$} \\
\hline 10 & 0.5 & 0.1 & 1.2 & 0.8 & 0.95 & 0.98 & 45.0 & 46.1 & 45.7 & 44.3 & 1.0 & 0.6 & 19.0 & 22.0 \\
\hline 20 & 1.1 & 0.7 & 3.3 & 1.4 & 0.98 & 1.07 & 38.9 & 41.5 & 42.9 & 43.3 & 2.7 & 1.1 & 17.0 & 20.0 \\
\hline 30 & 4.0 & 2.5 & 8.5 & 3.8 & 1.15 & 1.22 & 36.3 & 38.6 & 41.1 & 42.5 & 7.2 & 3.2 & 15.0 & 17.0 \\
\hline 40 & 4.8 & 4.1 & 9.4 & 7.2 & 1.20 & 1.24 & 34.6 & 37.3 & 40.0 & 41.5 & 8.2 & 6.0 & 13.0 & 16.0 \\
\hline 50 & 7.3 & 5.7 & 10.6 & 10.3 & 1.22 & 1.26 & 31.0 & 35.0 & 39.6 & 40.1 & 9.4 & 9.0 & 11.0 & 13.0 \\
\hline
\end{tabular}

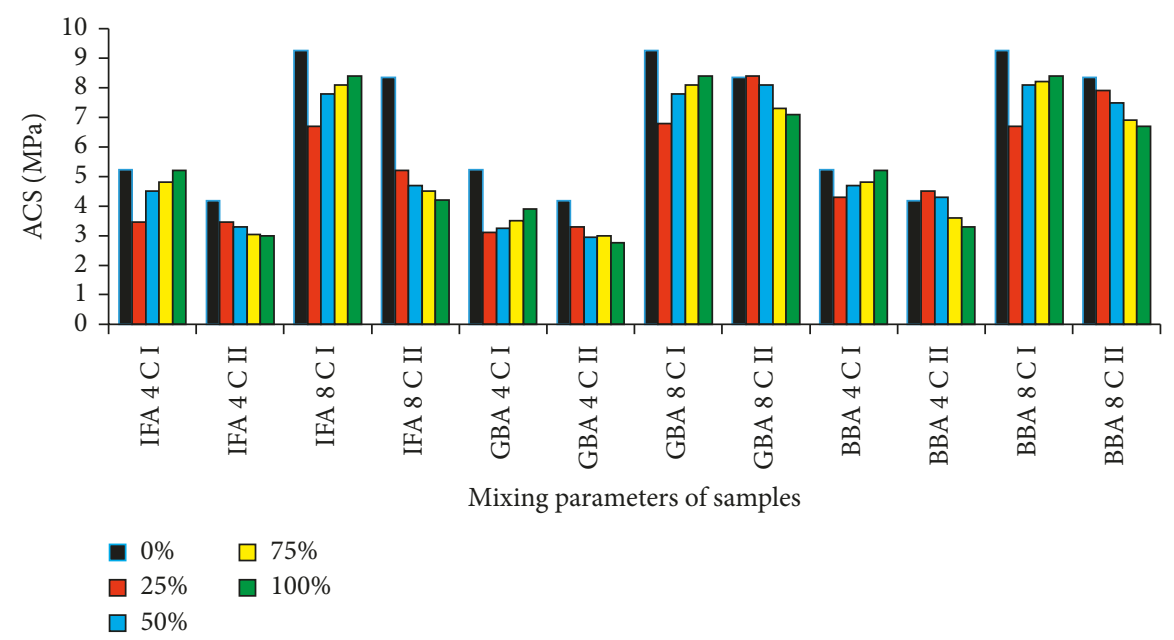

FIGURE 5: Relationship of ACS of the samples having different admixtures. IFA: İsken FA; 4: BC40; 8: BC80; C: CEM; GBA: Göknur BA; BBA: Bor BA.

During the substitution of pumice with fine material (IFA, GBA, and BBA), the reasons of decreasing the ACS values in the samples produced with CEM II are (a) the excess amount of calcareous found in CEM II cement and (b) the reaction between cement oxides and ashes, which influence mechanical properties.

As seen in Table 2 and Figure 6, the UW values of the samples that were produced with $100 \%$ pumice according to
BC40 and BC80 lightweight building material mixing calculations were approximately $20 \%$ lower than those that were produced with ashes. As increasing fine material in the samples produced with CEM I, CEM II, and IFA, the UW values showed an increasing trend. The reason for this is the UWs of IFA and BAs are higher than those of pumice. In the samples produced with GBA and BBA, the UW decreased as the ash ratio increased. However, this decrease is in 


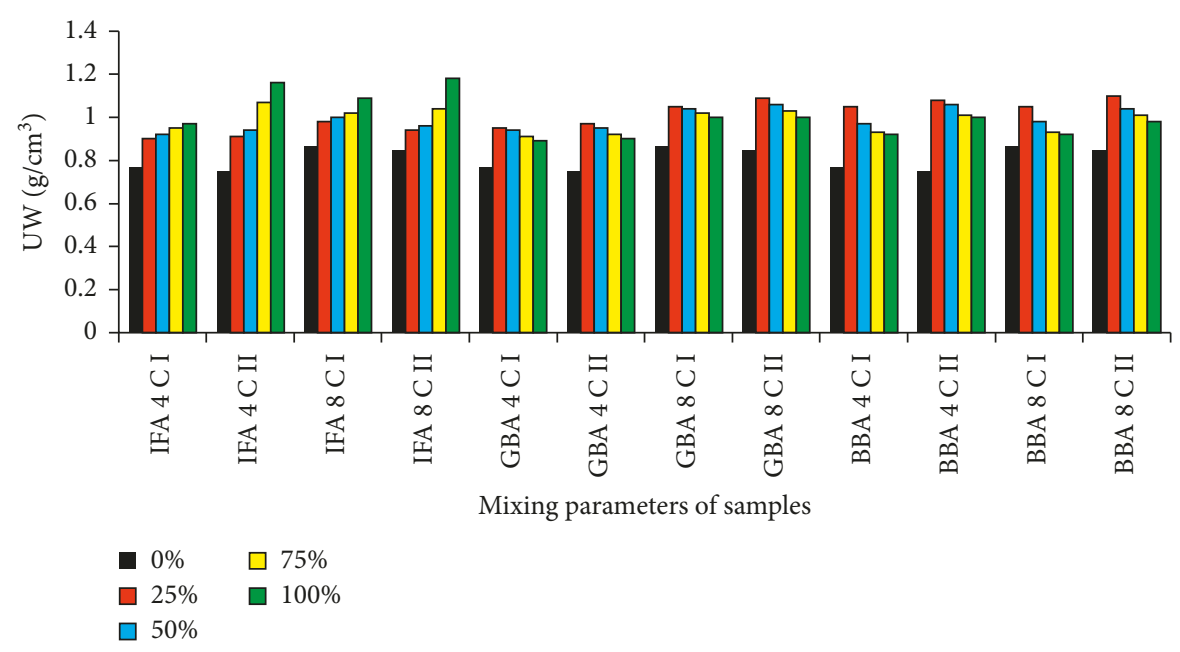

FIGURE 6: Relationship of UW of the samples having different admixtures. IFA: İsken FA; 4: BC40; 8: BC80; C: CEM; GBA: Göknur BA; BBA: Bor BA.

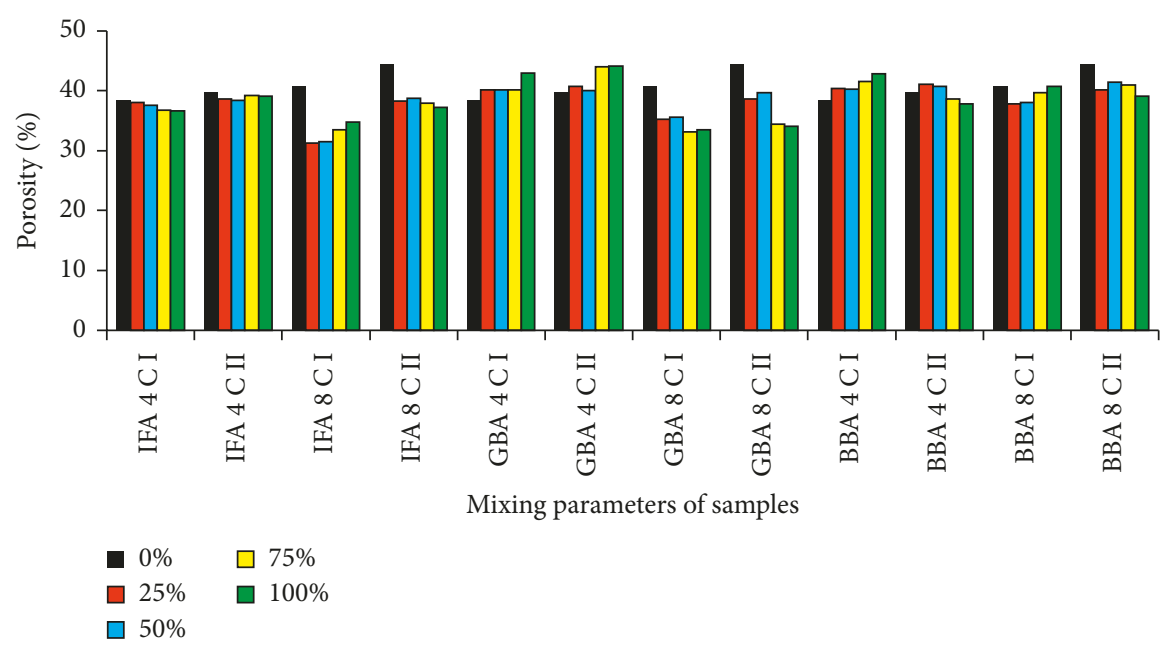

Figure 7: Relationship of porosity of the samples having different admixtures. IFA: İsken FA; 4: BC40; 8: BC80; C: CEM; GBA: Göknur BA; BBA: Bor BA.

negligible level. In addition, although all samples produced with ash show approximately $20 \%$ increase for the UW values, the products are in the class of lightweight building material.

In Table 2 and Figure 7, the porosities of the samples produced with CEM I, CEM II, and fine materials (IFA, GBA, and $\mathrm{BBA}$ ) according to $\mathrm{BC} 40$ and $\mathrm{BC} 80$ did not change very much, and the results were close to each other. However, the porosities of the samples produced with pumice were higher. This can be said to be due to the fact that very fine FA and BA particles fill the pores of the pumice.

The amount of cement (Table 3) used in the 5th group and in the production of samples including 100\% IFA, GBA, and BBA was determined according to the volume ratios. The BC40 standard could be achieved even with the IFAbased samples including 10\% CEM I and CEM II ratios. Similar result was also obtained from the GBA-based cemented (CEM I) samples. However, this result could not be obtained from cemented (CEM II) samples. This is due to the reaction of ashes and CEM II cement and originates from the inherent properties of the cement.

The samples including $100 \%$ BBA were produced in two groups according to grain distribution. In the first group (BBA1), samples with grain distribution of $0-1 \mathrm{~mm}$ and in the second group (BBA2), those of $0-8 \mathrm{~mm}$ were produced. The ACS values of BBA1, CEM I, and CEM II mixed samples could be reached to $\mathrm{BC} 40$ when they include more than $30 \%$ cement. The ACS values that comply with BC40 for BBA2 could be reached in samples including more than 30\% CEM I and 40\% CEM II (Table 3, Figure 8).

The porosities of samples produced with 100\% IFA, GBA, and BBA showed similar results with those produced with 10, 20, 30, 40, and 50\% (in volume) CEM I and CEM II (Table 3, Figure 9). However, parallel to the increase in volumetric amounts of cement, the porosity of the produced samples decreased in a similar way. 


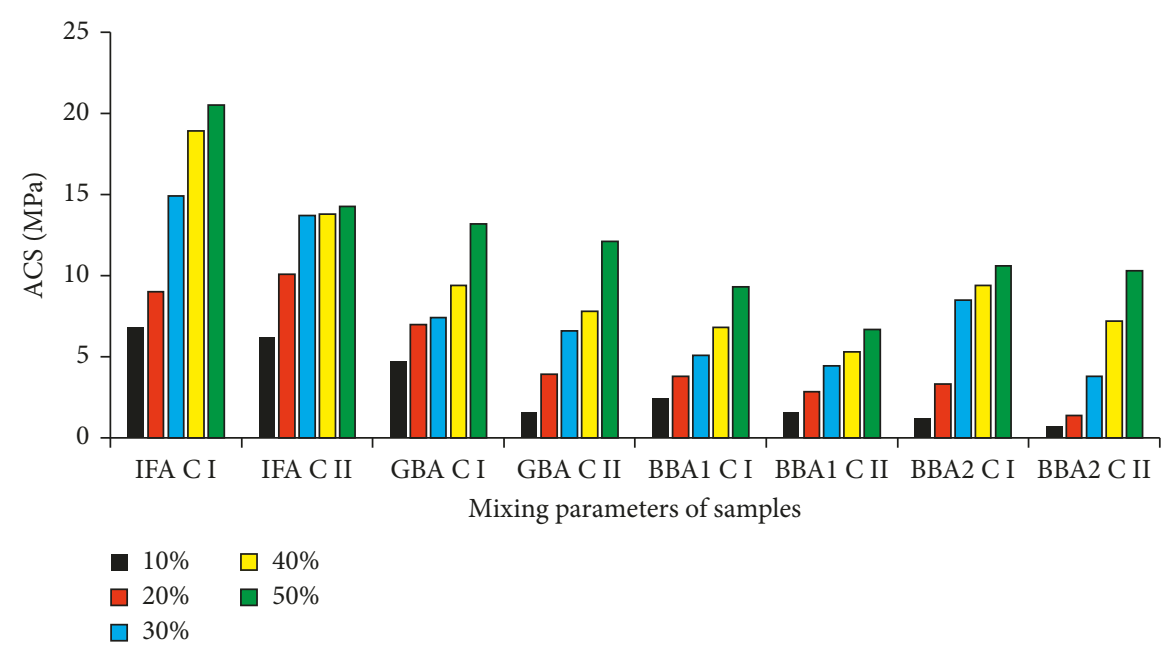

Figure 8: Relationship of ACS for FA- and BA-based sample. IFA: İsken FA; C: CEM; GBA: Göknur BA; BBA: Bor BA.

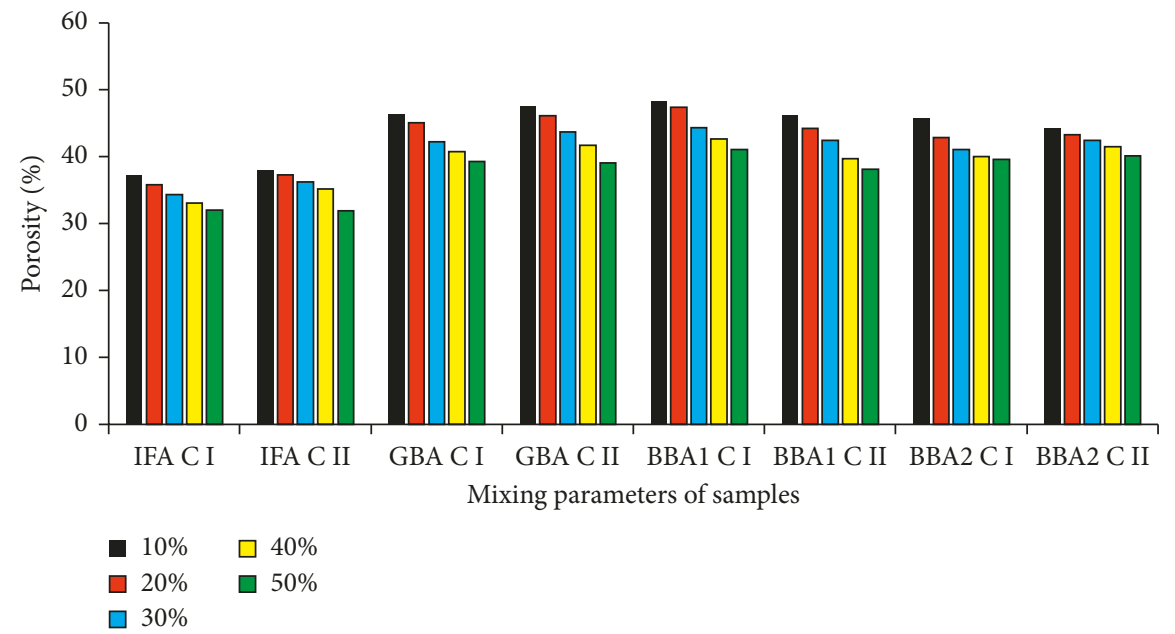

FIGURE 9: Relationship of porosity for FA- and BA-based sample. IFA: İsken FA; C: CEM; GBA: Göknur BA; BBA: Bor BA.

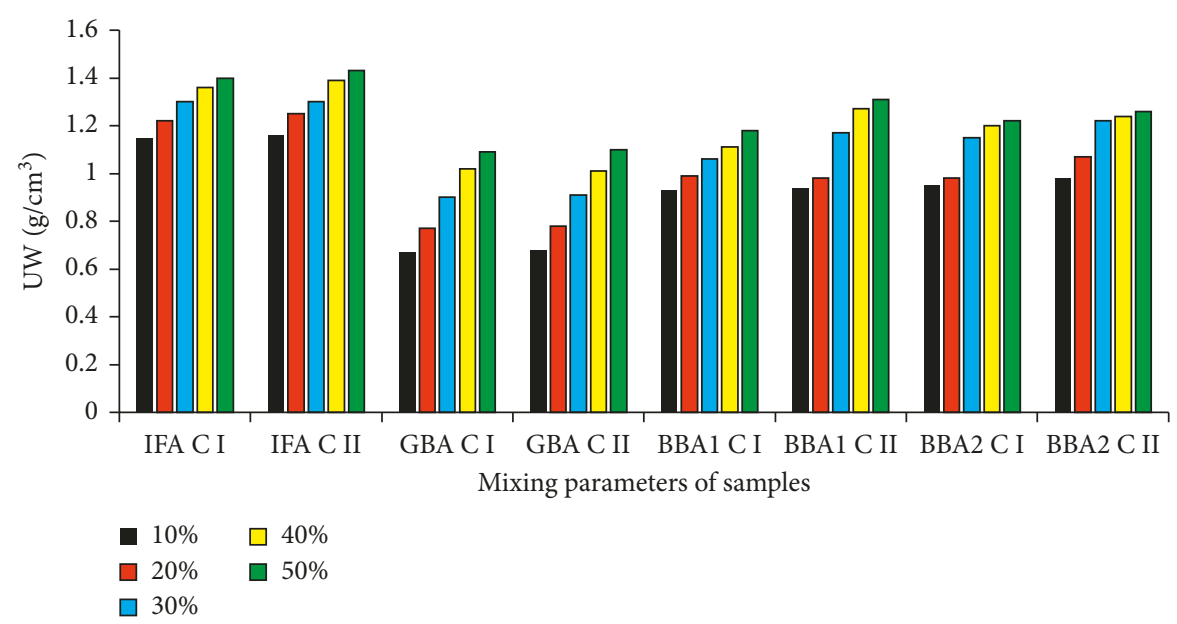

FIGURE 10: Relationship of UW for FA- and BA-based sample. IFA: İsken FA; C: CEM; GBA: Göknur BA; BBA: Bor BA. 
In terms of the UWs, similar results were obtained for all IFA-, GBA-, and BBA-based samples that were produced with 10, 20, 30, 40, and 50\% CEM I- and CEM II-type cement. As the volumetric cement ratio for each mixture increased, their UWs increased. The lowest UW was obtained in samples including GBA. The highest UW was found in samples produced with IFA due to higher value of IFA's UW (Table 3, Figure 10). Although the UWs of each sample varied, each was in the class of lightweight building materials.

\section{Conclusions}

This work has been carried out with the aim of finding solutions for the waste ash problem with known technologies in the building industry. For this purpose, waste ash is added to the mixture of constructive building block produced by pumice. $100 \%$ waste ash-based cemented samples were also produced. The physical and mechanical properties of the produced samples were determined and the following results were obtained:

(1) $100 \%$ pumice-based standard samples were produced for comparison to TS 3234. These samples must reach minimum ACS values of $4 \mathrm{MPa}$ for BC40 and $8 \mathrm{MPa}$ for $\mathrm{BC} 80$ at the end of 28 -day water curing period. In the samples produced with CEM I and IFA, the ACS values were increased in parallel with the increase in IFA fine material ratio. It was concluded that an average ACS of $4.51 \mathrm{MPa}$ was found for BC40 in cemented (CEM I) samples. Therefore, pumice-based lightweight building blocks with IFA additive can be produced for constructive purposes. The targeted results for the samples produced with CEM II could not be obtained.

(2) For the samples produced with CEM I and IFA, the ACS values increased with increasing IFA fine material ratio. The average ACS values of $8.12 \mathrm{MPa}$ for BC80 were obtained for 50, 75, and 100\% IFA-based samples. It was found that the IFA-additive pumicebased lightweight building blocks for constructive purposes can be produced. By using CEM II, the targeted results could not be obtained.

(3) For the CEM I and CEM II and GBA mixed samples for $\mathrm{BC} 40$, the targeted ACS value could not be achieved. On the other hand, for BC80, ACS values of the samples including 75 and 100\% GBA and CEM I and 25 and 50\% GBA and CEM II were above the standards, respectively.

(4) For BC40, ACS values of the CEM I and BBA mixed samples increased with increasing percentage of waste ash and found to be above the standard value with a minimum of $4.30 \mathrm{MPa}$. For the CEM II and BBA mixed samples, standard ACS values were found at 25 and $50 \%$ ratios of BBA. For BC80, the ACS values of samples including CEM I and BBA in 50,75 , and $100 \%$ mixture ratios were found to be above the standard values. ACS values for CEM II and BBA mixed samples were not reached the standard value.

(5) It is determined that lightweight concrete and building material for constructive purposes can be produced from 100\% IFA-, GBA-, and BBA-based cemented (CEM I and CEM II) material.

(6) ACS after freeze-thaw, UW, WAP, and porosity of all samples produced in this study are obtained in required values to lightweight concrete and building material for constructive purposes.

(7) ACS values of all samples after freeze-thaw are decreased about $20 \%$. It is similar with the obtained results from $100 \%$ pumice-based samples. Moreover, there are no significant adverse effects on visual inspection, and samples resistant to external influences can be produced.

(8) It was found that IFA is the most suitable fine material for producing pumice-ash-based cemented lightweight building materials.

The waste formation constitutes an inevitable problem in the majority of industrial establishments. In this study, BA and FA were used in order to solve the waste ash problem of industrial and thermal power plant. The lightweight building material obtained by using the effectiveness of pumice and ashes as raw materials and cement as a binder can be widely used as a constructive material in the construction sector. In this study, an important input to the ecosystem was provided using waste ashes, whose storage constitutes a problem. A contribution to the economy was also provided as well as the protection of environment with natural materials.

\section{Conflicts of Interest}

The authors declare that they have no conflicts of interest.

\section{Acknowledgments}

This study was supported by the Turkish Scientific and Technical Research Council (TUBITAK) 2241/B Programme, Project Grant no. 1139B411402723. Authors acknowledge ÇİMSA Cement Industry and Trade Inc. for providing CEM I and CEM II cements and Department of Civil Engineering and Center of Application and Research for Industrial Raw Material and Building Materials of Niğde Ömer Halisdemir University for laboratory conditions, editors, and referees for comments.

\section{References}

[1] N. Doğan-Sağlamtimur, A. Bilgil, M. Demir et al., "A reuse study from Niğde, Turkey: the conversion of industrial ash to geopolymer," Desalination and Water Treatment, vol. 57, no. 6, pp. 2604-2615, 2016.

[2] B. Postacıoğlu, "Beton Bağlayıcı Maddeler," cilt 1, Teknik Kitaplar Yayınevi, İstanbul, 1986.

[3] H. Yazıcı, Termik Santral Atiği Yapay Alçi-Uçucu Kül-Taban Külü Esasli Yapi Malzemesi Geliştirilmesi, Dokuz Eylül Üniversitesi, Fen Bilimleri Enstitüsü Doktora Tezi, İzmir, Turkey, 2004. 
[4] N. Doğan-Sağlamtimur, A. Bilgil, T. Cila et al., "Niğde fabrikası kazan altı küllerinden çimento bağlayıcılı hafif yapı elemanı üretimi," Çevre Bilim ve Teknoloji, vol. 1, pp. 50-57, 2016.

[5] INTES, Türkiye İnşaat Sanayicileri İşveren Sendikası İnşaat Sektörü Raporu Mart, 2014, http://www.intes.org.tr/content/ MArt-2014.pdf.

[6] İ. Yüksel, Ö. Özkan, and T. Bilir, "Kazanaltı külü ile briket üretimi," Gazi Üniversitesi Mühendislik-Mimarlık Fakültesi Dergisi, vol. 21, no. 3, pp. 527-532, 2006.

[7] R. Siddique, "Utilization of coal combustion by-products in sustainable construction materials," Resources, Conservation and Recycling, vol. 54, no. 12, pp. 1060-1066, 2010.

[8] M. L. D. Jayaranjan, E. D. van Hullebusch, and A. P. Annachhatre, "Reuse options for coal fired power plant bottom ash and fly ash," Reviews in Environmental Science and Bio/Technology, vol. 13, no. 4, pp. 467-486, 2014.

[9] Y. Bai, F. Darcy, and P. A. M. Basheer, "Strength and drying shrinkage properties of concrete containing furnace bottom ash as fine aggregate," Construction and Building Materials, vol. 19, no. 9, pp. 691-697, 2005.

[10] İ. Yüksel, T. Bilir, and Ö. Özkan, "Durability of concrete incorporating non-ground blast furnace slag and bottom ash as fine aggregate," Building and Environment, vol. 42, no. 7, pp. 2651-2659, 2007.

[11] K. Nataraj, S. M. Midun, K. M. Hari, G. M. Ganesh, and A. S. Santhi, "Bottom ash concrete," International Journal of Advanced Research in Mechanical and Production Engineering and Development, vol. 1, no. 1, pp. 6-11, 2013.

[12] E. Sancak and A. Şamandar, "The role of usage of selfconsolidating concrete with regard to sustainability," in Proceedings of International Sustainable Building Symposium, pp. 134-140, Ankara, Turkey, May 2010.

[13] İ. Bentli, A. O. Uyanık, U. Demir, O. Şahbaz, and M. S. Çelik, "Seyitömer termik santrali uçucu küllerinin tuğla katki hammaddesi olarak kullanimi," in Türkiye 19, Uluslararası Madencilik Kongresi ve Fuar, pp. 385-389, İzmir, Turkey, Haziran 2005

[14] D. Alkaya, "Uçucu küllerin zemin iyileştirmesinde kullanılmasının incelenmesi," Yapı Teknolojileri Elektronik Dergisi, vol. 5, no. 81, pp. 61-72, 2009.

[15] N. Phonphuak, S. Kanyakam, and P. Chindaprasirt, "Utilization of waste glass to enhance physical and mechanical properties of fired clay brick," Journal of Cleaner Production, vol. 112, pp. 3057-3062, 2016.

[16] P. A. M. Basheer, P. R. V. Gilleece, A. E. Long, and W. J. Mc Carter, "Monitoring electrical resistance of concretes containing alternative cementitious materials to assess their resistance to chloride penetration," Cement and Concrete Composites, vol. 24, no. 5, pp. 437-449, 2002.

[17] J. Deja, "Freezing and de-icing salt resistance of blast furnace slag concretes," Cement and Concrete Composites, vol. 25, no. 3, pp. 357-361, 2003.

[18] O. Ünal, A. Ergün, T. Uygunoğlu, and G. Kürklü, Hafif Agregal Elemanların Fiziko-Mekanik Özelliklerin Araştırılması ve Modellenmesi, TÜBİTAK, Project No: 109M391, Ankara, Turkey, 2008.

[19] Ş. G. Özkan and G. Tuncer, "Pomza madenciliğine genel bir bakiş," in 4. Endüstriyel Hammaddeler Sempozyumu, pp. 200-207, İzmir, Turkey, Ekim 2001.

[20] I. Demir, M. S. Başpınar, G. Görhan, E. Kahraman, and O. Akyol, "Pomza agregali hafif beton isil özelliklerine polistiren köpük ve uçucu kül katkisini etkileri, x. ulusal tesisat mühendisliği kongresi," in Binalarda Enerji Performansı Sempozyumu, pp. 911-916, İzmir, Turkey, Nisan 2011.

[21] O. Ünal, İ. Demir, and T. Uygunoğlu, "Pomza ve diyatomitin hafif blok eleman üretiminde kullanilmasinin araştirilması," in III. Ulusal Kırmataş Sempozyumu, pp. 107-113, İstanbul, Turkey, Aralık 2003.

[22] M. Eriç, Yapı Fiziği ve Malzemesi, Literatür Yayıncılık, İstanbul, Turkey, 1994.

[23] X. C. Qiao, B. R. Ng, M. Tyrer, C. S. Poon, and C. R. Cheeseman, "Production of lightweight concrete using incinerator bottom ash," Construction and Building Materials, vol. 22, no. 4, pp. 473-480, 2008.

[24] W. Wongkeo and A. Chaipanich, "Compressive strength, microstructure and thermal analysis of autoclaved and air cured structural lightweight concrete made with coal bottom ash and silica fume," Materials Science and Engineering A, vol. 527, no. 16-17, pp. 3676-3684, 2010.

[25] L. Blomqvist, A. Pfriem, and J. Johansson, "Temporary buildings in reusable lightweight material design," in Proceedings of World Conference on Timber Engineering, Vienna, Austria, August 2016.

[26] TS 3234, Bimsbeton Yapım Kuralları, Karışım Hesabı ve Deney Metotları, Türk Standartları Enstitüsü (Mining, placing, curing, mix design and methods of testing of pumice concrete), Turkish Standards Institution (TSE), Ankara, Turkey, 2005. 


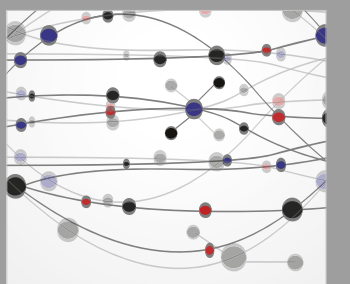

The Scientific World Journal
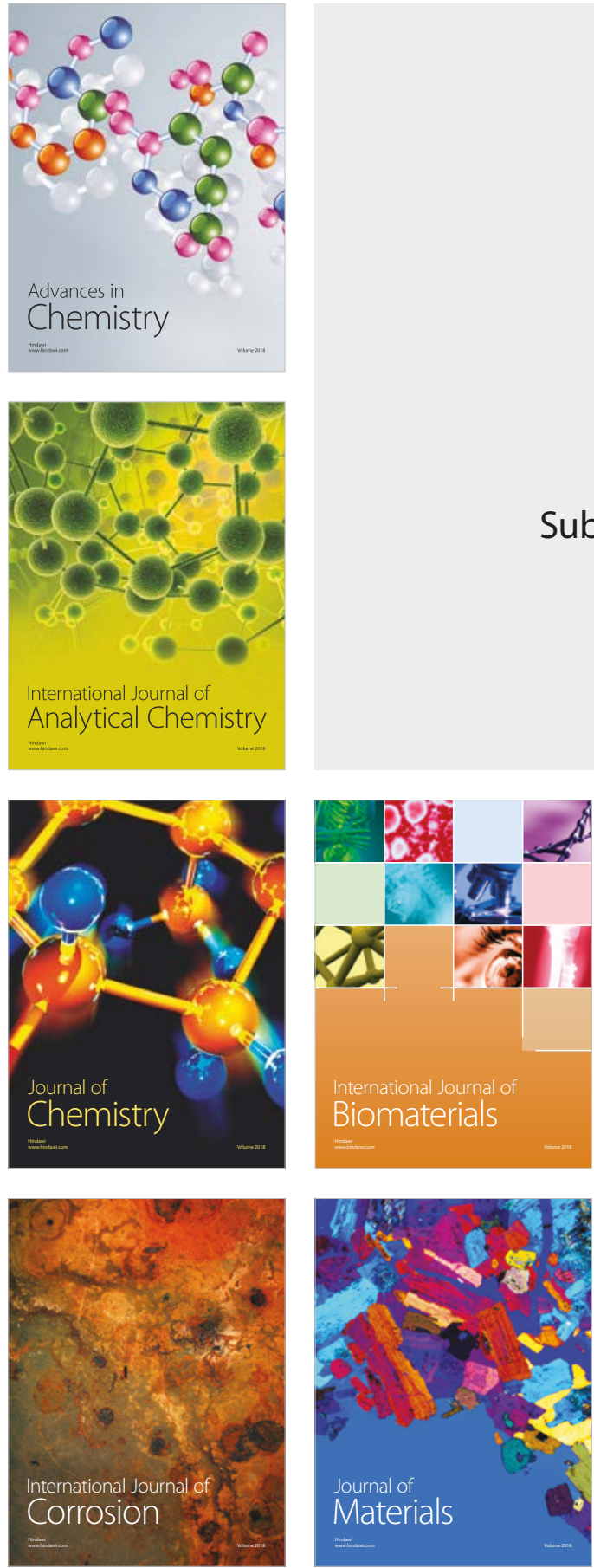

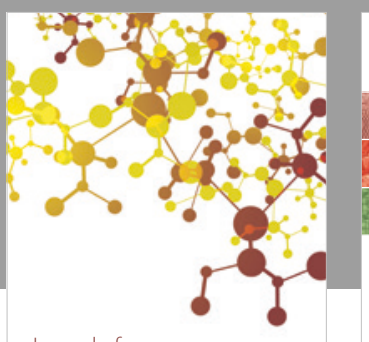

Journal of

Applied Chemistry
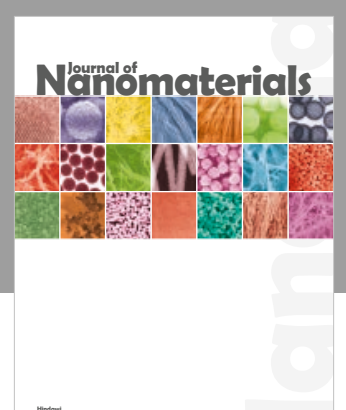

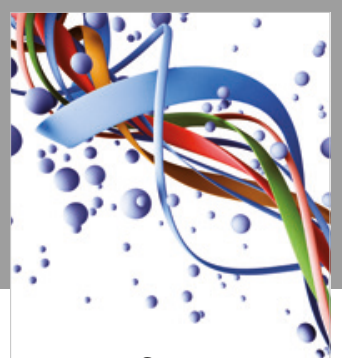

Scientifica

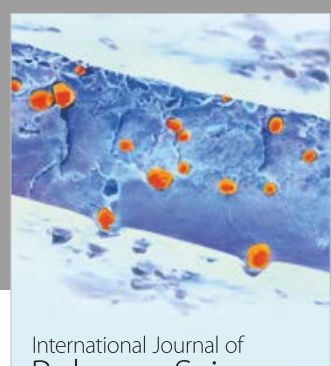

Polymer Science

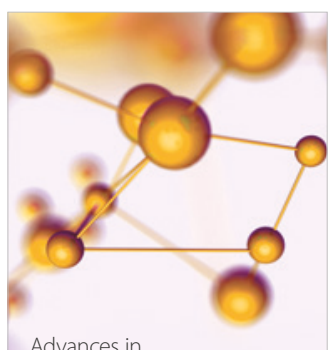

Physical Chemistry
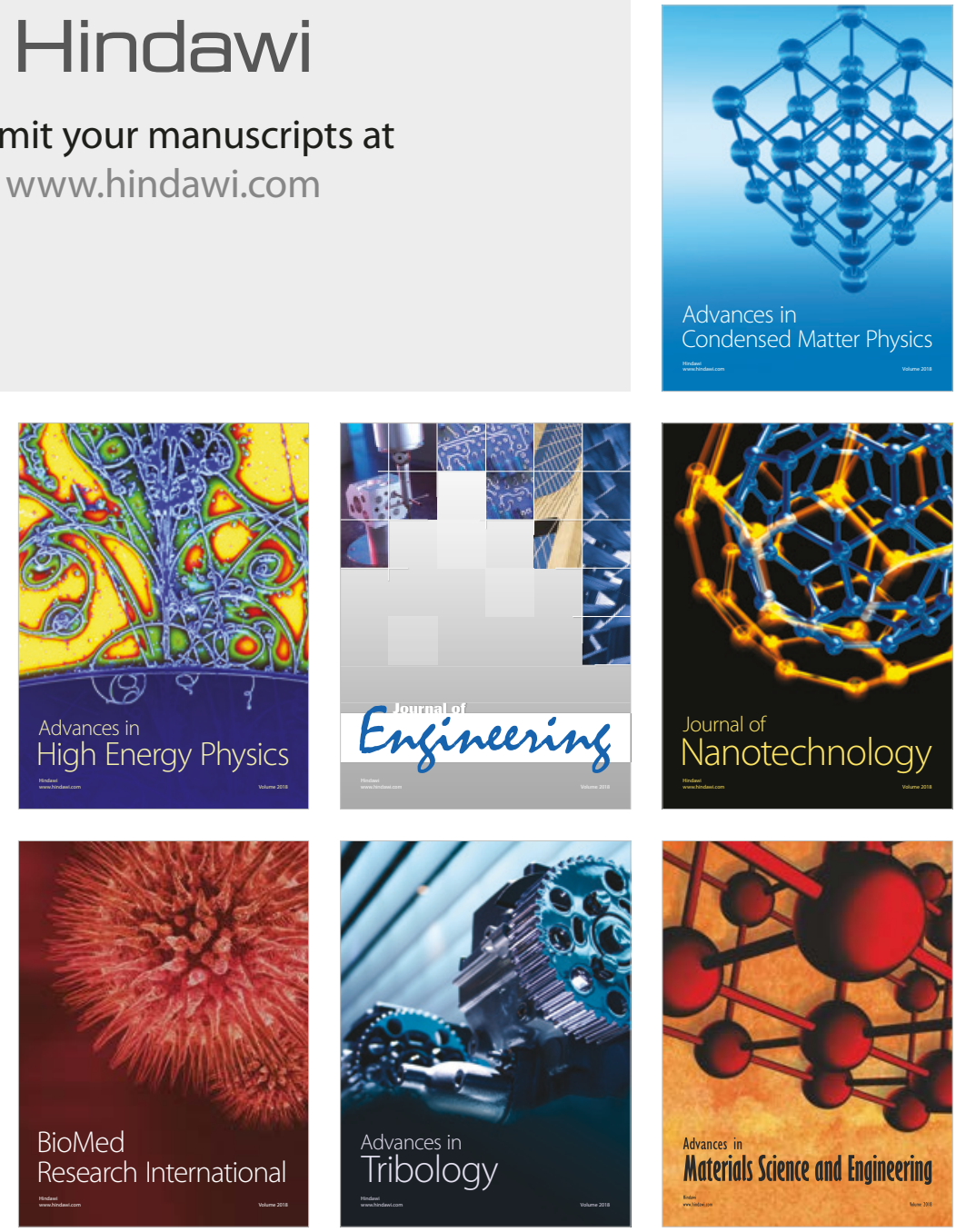